DOI:

Олена Казачінер, доктор педагогічних наук, дочент кафедри методики навчання мов і літератури КВНЗ “Харківська академія неперервної освіти”

\title{
ВИКОРИСТАННЯ ТЕХНОЛОГІЇ ЕНЕРДЖАЙЗИНГУ НА НАВЧАЛЬНИХ ЗАНЯТТЯХ “ТЕХНОЛОГІЇ ІНКЛЮЗИВНОЇ ОСВІТИ" ДЛЯ ВЧИТЕЛІВ ФІЛОЛОГІЧНИХ ДИСЦИПЛІН У СИСТЕМІ ПІДВИЩЕННЯ КВАЛІФІКАЦІЇ
}

У статті визначено особливості використання технології енерджайзингу як однієї з інтерактивних технологій. Вона застосовується з метою виклику заиікавлення навчальною темою, перетворення аудиторіі пасивних спостерігачів на активних учасників заняття. Енерджайзери можуть бути руховими, змагальними, на пробудження емоцій та почуттів до теми заняття та уваги. Обтрунтовано необхідність використання технології енерджайзингу в системі підвищення кваліфікачії вчителів філологічних дисииплін. Наведено приклади авторських вправ-енерджайзерів, які використовуються на навчальних заняттях "Технології інклюзивної освіти" (на прикладі вчителів іноземної (англійської) мови).

Ключові слова: інтерактивні технології; технологія енерджайзинг; вправи-енерджайзери; вчителі філологічних дисииплін; система підвищення кваліфікації; технології інклюзивної освіти.

Jim. 7.

Olena Kazachiner, Doctor of Sciences (Pedagogy), Associate Professor of the Methods of Teaching Languages and Literature Department Kharkiv Academy of Postgraduate Education

\section{USING ENERGIZING TECHNOLOGY AT THE CLASSES “TECHNOLOGIES OF INCLUSIVE EDUCATION” FOR PHILOLOGY TEACHERS IN THE SYSTEM OF POSTGRADUATE EDUCATION}

The article describes the features of using "energizing" technology as one of the interactive technologies. It is used to raise an interest in a training topic, transforming the audience of passive observers into active participants in the class. Energizers can be motorized, competitive, awaking emotions and feelings to the topic of the class, to awaken attention.

The necessity of using "energizing” technology in the system of postgraduate education of philological disciplines teachers is substantiated. Examples of author exercises-energizers used in "Inclusive Education Technologies" training sessions (for example, foreign (English) teachers) are given.

Thanks to the use of "energizing" technology at the educational sessions language and literature teachers have the opportunity not only to acquire a certain amount of theoretical knowledge and practical skills on the problem of inclusive education, but also, through participation in activities of this type, to analyze their own views, positions, certain stereotypes regarding the involving children with special educational needs into education with peers of typical development in institutions of general secondary education.

It was determined that an energizer was a mobile game that could be a certain functional load - grouped into mini-groups, acquaint participants, relieve tension and fatigue, etc. There should not be a great amount of energizers. However, their application is mandatory, if the effectiveness of the group is reduced because of fatigue, lack of attention, monotony of tasks or long-term or intense intellectual activity. Energizer can be not only a good start of a day or a task in terms of increasing energy in the group or relieving the voltage, but it can become a short setup on a specific topic.

Keywords: an interactive technologies; "energizing” technology; energizers; teachers of philological disciplines; a system of postgraduate education, inclusive education technologies.

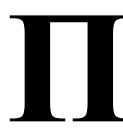

остановка проблеми. Інтерактивні методи навчання на сьогодні $€$ актуальним способом роботи викладача в аудиторії, тренера в групі та педагога в будь-якому освітньому закладі. Інтерактивні методи навчання, на відміну від традиційних, базуються на активній взаємодії учасників навчального процесу, при цьому основна увага надається взаємодії слухачів між собою. Такий підхід дозволяє активізувати навчальний процес, зробити його більш цікавим та менш втомлюваним для учасників.

Важливо викликати інтерес до навчальної теми, перетворювати аудиторію пасивних спостерігачів на активних учасників заняття. Якщо викладач у свойй роботі буде використовувати активні форми та методи навчання, то це важливе питання буде розв'язаним 


\section{ВИКОРИСТАННЯ ТЕХНОЛОГЇ ЕНЕРДЖАЙЗИНГУ НАНАВЧАЛЬНИХ ЗАНЯТТЯХ “ТЕХНОЛОГЇ̈ ІНКЛЮЗИВНОЇ ОСВІТИ” ДЛЯ ВЧИТЕЛІВ ФІЛОЛОГІЧНИХ ДИСЦИПЛІН У СИСТЕМІПДВИЩЕННЯКВАЛФІКАЩЇ̈}

саме собою. Активні форми навчання будуються на інтерактивних методах, коли існує взаємозв'язок не лише між викладачем i слухачем, а й між слухачами в навчанні. До таких належить і так звана технологія енерджайзингу.

Надзвичайно важливим нам здається застосування цієї технології на навчальних заняттях у системі підвищення кваліфікації. Актуальність її використання зумовлена ще й тим фактом, що нині гостро постає проблема неготовності вчителів до роботи 3 дітьми, які мають особливі освітні потреби, має місце наявність психологічних бар'єрів та професійних стереотипів учителів. У цьому ракурсі особливого значення набуває проблема розвитку інклюзивної компетентності вчителів, зокрема філологічних дисциплін, як складової їхньої професійної компетентності.

Ураховуючи нові вимоги до педагога в умовах модернізації освіти, вважаємо, що важливу роль у створенні умов для розвитку інклюзивної компетентності вчителів філологічних дисциплін мають відіграти заклади післядипломної педагогічної освіти. Необхідність розвитку інклюзивної компетентності вчителів є сьогодні актуальною та впроваджується лише нещодавно, тому оволодіти інклюзивними знаннями та вмінням вчителі-практики можуть у післядипломній освіті.

Завдяки використанню технології енерджайзингу на навчальних заняттях учителі мов і літератури мають можливість не лише оволодіти певним обсягом необхідних теоретичних знань та практичних умінь із проблеми інклюзивної освіти, а й шляхом участі у вправах такого типу переглянути власні погляди, позиції, іноді - певні стереотипи щодо залучення дітей із особливими освітніми потребами до навчання разом із однолітками типового розвитку в закладах загальної середньої освіти.

Аналіз останніх досліджень та публікацій. Свідчить про те, що технологія енерджайзингу належить до переліку інтерактивних технологій навчання, проте розглядалася надто поверхнево.

Проблему застосування інтерактивних технологій в освітньому процесі порушували такі дослідники, як А. Кух [3; 4], О. Пометун, Л. Пироженко [5], Г. Сухорукова [6] та інші.

Отже, як бачимо, питання використання технології енерджайзингу на навчальних заняттях “Технології інклюзивної освіти”, зокрема для вчителів філологічних дисциплін, не було предметом спеціальних наукових пошуків, проте на сучасному етапі потребує обов'язкового висвітлення.
Мета дослідження полягає у визначенні особливостей використання технології енерджайзингу на навчальних заняттях “Технології інклюзивної освіти” для вчителів філологічних дисциплін у системі підвищення кваліфікації.

Виклад основного матеріалу. Енерджайзери, або техніки підвищення / переключення уваги застосовуються у випадках:

- коли необхідно зняти напругу або підвищити енергію та емоційний тонус у групі;

- перед зміною діяльності або переходу від одного етапу до другого;

- обов'язково - після перерви (на обід або кавабрейки) перед початком роботи.

Енерджайзер може бути не лише хорошим початком дня чи завдання в сенсі підвищення енергії в групі або зняття напруги, але може стати й коротким налаштуванням на певну тему введенням в наступне завдання. Часто деякі учасники сприймають енерджайзер як безглузду й непотрібну гру, тому використання іiї у зв'язку з подальшою темою може допомогти сприйняти їі як частину програми. Окрім цього, важливо грамотно враховувати особливості групи i готовність кожного учасника до виконання тієї чи іншої вправи [7, 67 - 68].

Енерджайзерів не повинно бути багато $(2-3$ на одному тренінгу з інтервалом одна на $2-3$ години). Проте їх застосування обов' язкове, якщо ефективність роботи групи зменшується через втому, брак уваги, одноманітність завдань або довготривалу чи інтенсивну інтелектуальну діяльність [1, 12 - 13].

Як правило, це рухлива гра, яка може бути певним функціональним навантаженням об'єднати в міні-групи, познайомити учасників, зняти напругу і втому, тощо.

Звичайно, тренер має відчувати настрій групи - чи потребують учасники такої вправи, чи може іiі варто провести пізніше.

Не варто забивати програми великою кількістю таких вправ, бо головна мета нашої роботи все ж таки полягає в іншому. Але й нехтувати ними не варто. Достатньо тримати у пам'яті хоча б декілька енерджайзерів, або за умови досвідченої групи покласти їх добір та проведення на самих учасників. Слушно використати даний тип вправ і для розмежування складних теоретичних блоків чи запальних дискусій, особливо якщо є потреба підбадьорити групу [2, 28 - 29].

Наведемо кілька прикладів вправенерджайзерів, які ми використовуємо на навчальних заняттях “Технології інклюзивної 


\section{ВИКОРИСТАННЯ ТЕХНОЛОГЇЕНЕРДЖАЙЗИНГУ НАНАВЧАЛЬНИХ ЗАНЯТТЯХ “ТЕХНОЛОГЇ̈ ІНКЛЮЗИВНӦ̈ ОСВІТИ” ДЛЯ ВЧИТЕЛІВ ФІЛОЛОГІЧНИХ ДИСЦИПЛІН УСИСТЕМІПДВИЩЕННЯКВАЛФІКАЩІІ}

освіти” для вчителів філологічних дисциплін у системі підвищення кваліфікації (на прикладі вчителів іноземної (англійської) мови):

1) SEN students face many difficulties, which can range from mild to severe. Read the descriptions of the four main categories of SEN and decide if the statements are true or false.

Cognition and learning

This category includes general learning difficulties and specific learning difficulties. Students with general learning difficulties usually make slower progress than their peers in literacy, numeracy, and general understanding. They might have problems with generalizing or understanding abstract ideas. Students with specific learning difficulties may only have problems in one area of learning, for example reading and writing, and no problems in other areas. Specific learning difficulties include dyslexia (difficulties with reading and spelling) and dyspraxia (difficulties with coordination and motor skills). Some students may have more than one specific learning difficulty. These difficulties can affect a range of areas, including memory, concentration, organization, communication, and social skills.

\section{Communication and interaction}

This category covers a wide range of problems, including disordered and delayed language. Speech and language difficulties can be productive and/or receptive, and will often impact on a student's ability to learn another language. Students have problems with productive language when they have difficulty producing words, expressing their thoughts, and making themselves understood. They may speak in short sentences using limited vocabulary and incorrect grammar. Students have problems with receptive language when they have difficulty understanding what another person is saying. They might be slow to respond to questions and instructions. This group includes students with autism spectrum condition (ASC), such as Asperger's syndrome.

Social, emotional, and behavioural difficulties (SEBD)

We use this term to describe students with emotional difficulties, very challenging behaviour, or serious psychological difficulties. It can sometimes be difficult to decide when poor behaviour should be treated as a SEN. We use SEBD to describe a problem behaviour which is severe, not age appropriate, happens frequently, and occurs in different situations. This category includes students who are continually disruptive, challenging towards the teacher, withdrawn, impulsive, or hyperactive. This group includes students with attention deficit hyperactive disorder (ADHD). Students with SEBD are often capable of learning another language if their behaviour can be managed in class.

\section{Gifted and talented}

"Gifted and talented" is the term applied to students who are achieving, or who have the potential to achieve, at a level significantly beyond the rest of their peer group. Gifted describes students who have the ability to excel academically in one or more subjects such as English, Maths, or foreign languages. Talented describes students who have the ability to excel in practical skills, such as sport, music, or art. A gifted and talented student may not always stand out from the rest of the class. Some students are confident and keen to show their ability, but others may hide their ability in order to fit in.

2) Find out about any famous people in your country who have dyslexia, and who you think your students would be interested in. Use the information to create a lesson for your classes to raise awareness of dyslexia and encourage dyslexic and non-dyslexic students to see the positive side of dyslexia.

3) What does it feel like to have dyslexia? Read the following passage and answer the questions. Check your ideas in the Feedback.

Eech berson wth dsylexia expeereunses it bifrently. Homever, thair ar sum comun difikultees wth reeding aud riting. Sumtimes leters ar erversed or tnrned over, or the leters in a mord ar mixt ud or omitid. Swall wrds can be cnofused toher swall wrds, and okayshunly wurds ar felt out comdletely. Peepl wit dyslexia ofn try to spel unfamiliar wirds fonetically and the saym wird cau de spled sevral difrunt awys ou oue bage. Ofn they hav brodlems maching leters to the sonuds thay erpresent witch meens wurd recognishun dose uot decowe antomatic.

- What strategies did you use to decode the reading?

- What impact could this type of reading difficulty have on learning?

4) Comment on the following questions: When might children with disabilities be best served by attending a special school? When might children with disabilities be best served by attending an inclusive mainstream school?

5) How can you incorporate a wide diversity of learners in your own classroom or school, and still enhance your teaching and learning process? Ask questions and offer suggestions; share experiences and pose problems.

Try to think of more practical tips that could help to accommodate varying needs in the classroom and please share them with.

6) Which methods of work have you been using in the learning process having in 


\section{ВИКОРИСТАННЯ ТЕХНОЛОГЇ̈ЕНЕРДЖАЙЗИНГУ НАНАВЧАЛЬНИХ ЗАНЯТТЯХ \\ “ТЕХНОЛОГЇ̈НКЛЮЗИВНОЇ ОСВІТИ” ДЛЯ ВЧИТЕЛІВ ФІЛОЛОГІЧНИХ ДИСЦИПЛІН У СИСТЕМІ ПДВИЩЕННЯ КВАЛІФІКАЦІї}

consideration the fact that in your class there are two pupils with disabilities?

7) All parents want the best for their children. When making decisions about education for a disabled child, parents may not know what to do. They may find it difficult to deal with the child on their own, but feel that they as parents should be able to cope at home. They may feel ashamed and isolated.

They may worry about costs for the special needs their child has. They may worry that a regular school won't be able support their child to learn. And like Jacqui, a mother of a child with a disability you will meet later in this week, they may worry that their child won't be happy.

Here are two more parent stories to read and watch:

- In this video clip made by Human Rights Watch a mother, Sisanda Hani from South Africa, talks about the support she received from an NGO.

- Even from a developed country like Canada, parents lead the way in lobbying for inclusive education. Listen to Zuhy Sayeed, leader of the Community Living Association, speak about parents' role in creating inclusive education.

Are there any other family factors in your community, country, or culture that could affect disabled children's attendance in school? What do you think are the rights and responsibilities of parents of children with disabilities?

8) Read the chapter three from Inclusive Education in Low Income countries, A Resource for Teacher Educators, Parent Trainers and Community Development Workers and the extract from UNESCO'S publication, From Embracing Diversity: Toolkit for creating inclusive, learning-friendly environments. Booklet 2 Working with Families and Communities to create an ILFE below.

What kinds of support do you think families might need in your context? How can they be helped to prepare their children for inclusive education?

9) Write about how you imagine your role within the learning support team in helping to overcome the barrier to inclusion and then share it with others

10) We've been discussing inclusion now, but there has been little attention paid to teachers' roles in inclusion. The ideas about all children learning together sounds ideal, but what does that mean when you are a teacher standing in front of a class?

11) Meet your new learner, Sinethemba! Sinethemba is coming to a new school after losing the hearing in one ear from a viral infection some time ago. The hearing in the other ear is not very good. She can hear you when you speak in a small group or one-to-one basis, but when there is a lot of noise around her with many people talking, she can't hear anything. She speaks normally because she has heard the spoken word for most of her life.

Sinethemba had gone to a previous school before coming to this school, but she had found it difficult to learn. In the previous school the teacher made little effort to include Sinethemba, so she struggled to understand and was often left out.

The teacher often faced the board or turned to the side while speaking. The biggest challenge though, was his unwillingness to try even when Sinethemba's family explained these challenges to him. This hurt Sinethemba the most. Now she is very worried about attending the new class.

Respond to these statements below and write a short piece for another learner to review:

1. Identify 3 challenges Sinethemba might face when she starts school?

2. For each of the three challenges, identify possible solutions that may be able to address these challenges.

3. Identify the members of community that you think could help you?

12) We would like you to think of a particular child with a disability. This child can be real or imaginary. Think about how you could accommodate his/her particular individual needs, starting from entering into your classroom.

Think about how your classroom is laid out - can they move freely to their desk? Think about where the desks are situated - where would the best seat for this child be?

Think about lighting and noise, as well as what teaching strategies and accommodations you might need to make for board and written tasks. Think about your assessment strategies - would these accurately assess his/her understanding?

Some areas may not be applicable while others may need a lot of modifications. Your child may have a specific learning disability, so accessing may not be a challenge, but modifying your teaching strategies and assessment methods may be.

Make notes on accommodating the child in your journal. If you have any difficulties, post your concerns below.

13) Can you identify your social capital? In this exercise, you should be able to create a quick mind map of the resources available to you. Allow about 15 minutes for this activity, and once you have completed it, you can participate in the discussion below.

1. Take a sheet of paper

2. Write 'inclusive education' and your name in 


\section{ВИКОРИСТАННЯ ТЕХНОЛОГЇЕНЕРДЖАЙЗИНГУ НАНАВЧАЛЬНИХ ЗАНЯТТЯХ “ТЕХНОЛОГЇ̈ ІНКЛЮЗИВНӦ̈ ОСВІТИ” ДЛЯ ВЧИТЕЛІВ ФІЛОЛОГІЧНИХ ДИСЦИПЛІН УСИСТЕМІПДВИЩЕННЯКВАЛФІКАЦЇ}

the centre of your paper. Next draw 3 lines away from your name in each direction. Write 'Bonding', 'Bridging' and 'Linking' at the end of each line.

3. Go back to your exercise where you identified the resources in your community that could provide support to schools trying to address inclusion. Try to merge the two lists. Now add the people (the families, the friends, the neighbours, the principal or school head, the officials of the school governing body, the administrative officers, grocery shop owners and neighbourhood businesses, faith-based communities, government officials, etc.) around you who have shown or might show any kind of interest in issues of disability. You can include people you have interacted with in this course.

4. Next decide where each name you have written down fits - either under 'Bonding', 'Bridging' or 'Linking'. Write those names under one of the three headings.

14) Can you provide an example of where cooperation has resulted in bringing about a more inclusive environment?

Висновки 3 даного дослідження i перспективи подальших розвідок у даному напрямку. Таким чином, з усього сказаного вище можна дійти висновку про те, що технологія енерджайзинг $\epsilon$ однією 3 ефективних інтерактивних технологій, яку викладач може застосовувати в освітньому процесі під час проведення лекційних, практичних та семінарських занять. Енерджайзером $\epsilon$ тренінгова вправа, яка використовується для стимулювання й “підзарядки” учасників під час навчання, концентрації уваги, випуску емоцій тощо. Енерджайзери можуть бути руховими, змагальними, на пробудження емоцій та почуттів до теми заняття та уваги.

Питання використання технології енерджайзингу на навчальних заняттях “Технології інклюзивної освіти”, зокрема для вчителів філологічних дисциплін, не було предметом спеціальних наукових пошуків, проте на сучасному етапі потребує обов'язкового висвітлення.

У дослідженні було наведено кілька прикладів вправ-енерджайзерів, які ми використовуємо на навчальних заняттях “Технології інклюзивної освіти” для вчителів філологічних дисциплін у системі підвищення кваліфікації (на прикладі вчителів іноземної (англійської) мови).

Уважаємо, що предметом подальших наукових пошуків у напрямі окресленої проблеми може стати, по-перше, здійснення більш чіткої класифікації вправ цієї технології, по-друге, розробка вправ із використанням технології енерджайзингу, які можуть стосуватися різноманітних тем курсів підвищення кваліфікації вчителів філологічних дисциплін.

\section{ЛІТЕРАТУРА}

1. Слігулашвілі М., Федорович І., Пономарьов С. Організація навчання з питань дискримінації. Практичний посібник. Київ, 2015. 136 с.

2. Інтерактивні методи викладання. Практичні поради для суддів-викладачів. Київ: ФОП Демчинський О.В., 2017. 64 с.

3. Кух А.Н. Интерактивные технологии формирования профессиональных качеств будущих учителей физики. Новые технологии в преподавании физики: школа и ВУЗ (НТПФ-IV), 14 - 17 марта 2005 г. : сборник аннотаций. Москва: Типография МПГУ, 2005. 80 с.

4. Кух А.Н. Интерактивные методы обучения и их применение в высшей школе. Преподавание физики в высшей школе: научно-методический журнал. № 31. Москва, 2005. 175 с. С. 14-17.

5. Пометун О., Пироженко Л. Інтерактивні технології навчання: теорія і практика. Київ, 2002. $136 \mathrm{c}$.

6. Сухорукова Г. Інтерактивна взаємодія суб' єктів навчально-пізнавальної діяльності в педагогічному процесі. Методика навчання інформатики та IКТ. №4. 2012. С. 27-31.

7. DIALOGUE BOX. Підходи та практики 3 молодіжних проектів для порозуміння та діалогу: збірка матеріалів та методик. Інша освіта, 2015. 83 с.

\section{REFERENCES}

1. Yelihulashvili, M., Fedorovych, I. \& Ponomarov S. (2015). Orhanizatsiya navchannya $\mathrm{z}$ pytan dyskryminatsiyi [Organization of learning the discrimination problems]. Practical guide. Kyiv, 136 p. [in Ukrainian].

2. Interaktyvni metody vykladannya. Praktychni porady dlya suddiv-vykladachiv (2017). [Interactive methods of teaching. Practical tips for judgesteachers]. Kyiv: FOP Demchynskyy O.V., 64 p. [in Ukrainian].

3. Kuh, A.N. (2005). Interaktivnye tehnologii formirovanija professionalnyh kachestv budushih uchitelej fiziki [Interactive technologies of forming future Physics teachers' professional qualities]. New technologies in Physics teaching: school and higher educational establishment, March, 14 - 17, 2005: collection of annotations. Moskva: Tipografija MPGU, 80 p. [in Russian].

4. Kuh, A.N. (2005). Interaktivnye metody obuchenija i ih primenenie v vysshej shkole [Interactive teaching methods and their using in high school]. Teaching Physics in high school: scientific 
and methodical journal. No. 31, Moskva, 175 p., pp. 14-17. [in Russian].

5. Pometun, O. \& Pyrozhenko, L. (2002). Interaktyvni tekhnolohiyi navchannya: teoriya $i$ praktyka [Interactive teaching technologies: theory and practice]. Kyiv, 136 p. [in Ukrainian].

6. Sukhorukova, H. (2012). Interaktyvna vzayemodiya subyektiv navchalno-piznavalnoyi diyalnosti v pedahohichnomu protsesi [Interaction of subjects of cognitive activity in educational process]. Methods of teaching Computer Science and ICT. No. 4, pp. 27-31. [in Ukrainian]

7. DIALOGUE BOX (2015). Pidkhody ta praktyky z molodizhnykh proektiv dlya porozuminnya ta dialohu [Approaches and practices of youth projects for understanding and dialogue]. Collection of materials and methods. Other education, $83 \mathrm{p}$. [in Ukrainian].

Стаття надійшла до редакції 06.02.2019

УДК 376.64(091)(438)

DOI:

Ореста Карпенко, доктор педагогічних наук, доцент кафедри соціальної педагогіки та корекиійної освіти Дрогобиџького державного педагогічного університету імені Івана Франка

\section{ПЕРЕДУМОВИ СТАНОВЛЕННЯ ФОРМ ОПІКИ НАД ДІТЬМИ ПОЛЬЩІ (історико-педагогічний аспект)}

У статі розкрито еволюцію форм опіки над дитиною у Польщі. Благодійність була однією з перших форм опіки. Опіка здійснювалася в основному через костел або релігійні інституиії. Система опіки в Польщзі розвивалася швидко, а інституції, які надавали допомогу дітям, було щораз більше. Громадсько-педагогічній інічіативі у царині опіки над дітьми-сиротами призвели до утворення благодійних товариств, які у складних соиіально-економічних умовах створювали опікунські установи, дбали про задоволення потреб дітей. 3міст опікунсько-виховної діяльності, їі аксіологічні домінанти змінювалися під впливом суспільних явищ, ступеня цивілізаційного розвитку.

Ключові слова: опіка; виховання; благодійні товариства; будинки сиріт; притулки; виховний дім; Польща.

Jim. 15.

Oresta Karpenko, Doctor of Sciences (Pedagogy), Assosiate Profesor of the Social Pedagogy and Special Education Department,

Drohobych Ivan Franko State Pedagogical University

\section{PREREQUISITES OF THE FORMATION OF FORMS OF CUSTODY OF CHILDREN IN POLAND (historical and pedagogical aspect)}

The article reveals the evolution of forms child's custody in Poland. Charity was one of the first forms of custody. Custody was carried out mainly through a church or religious institution. From the XIII century asylum began to arise, the purpose of which was to provide the basic needs: physical security, religious and moral education, and sometimes teaching reading, writing and mathematics. The emergence of orphanhood and homeless children was generated by war, poverty or the epidemic. Therefore, it was important to create shelters, orphanages, as well as other cells in which children would receive support and assistance.

In churches and religious communities, the trusteeship and educational function was performed by hospitals and shelters, which, on the basis of Christian charity, provided support and assistance to the needy and abandoned children. Over time, the placement of natural and social orphans in foster families was less associated with the activities of charitable institutions. In 1775, a central body for the management of public charity was established, entitled "Commission on Hospitals".

The system of care in Poland developed rapidly, and the institutions that provided assistance to children were ever more numerous. The community-pedagogical initiative in the field of orphaned children care led to the formation of charitable societies, which, in difficult socio-economic conditions, established trusteeship institutions, took care of the needs of children. Public welfare of children on ethnic lands during the Austro-Hungarian period was partial, not covering all its units. The measures of the Austro-Hungarian state, aimed at providing elementary care to orphans, did not meet the expectations of the population and did not bring the desired results.

The content of the guardian-educational activity, its axiological dominant changed under the influence of social phenomena, the degree of civilization development. The organization of guardianship was conditioned by threatening social phenomena, the struggle for survival, wars that exacerbated the problems of orphanhood, poverty 